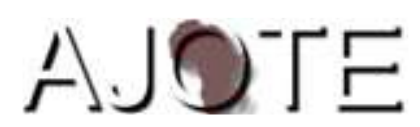

African Journal of Teacher Education

ISSN 1916-7822. A Journal of Spread Corporation

Volume $8 \quad 2019 \quad$ Pages 344-360

\title{
Role of parents in school management: A focus on decision making and accountability in resource provision in pre-primary schools in Embu County, Kenya
}

\author{
Ireri Jeremiah Wanjau and Nyakwara Begi (PhD) \\ (jeremiaireri@gmail.com | begi.nyakwara@ku.ac.ke) \\ Department of Early Childhood \& Special Needs Education. \\ Kenyatta University, Kenya
}

\begin{abstract}
The provision of adequate resources should be supported with strong and transparent accountability systems to enhance effective use of resources in schools to boost children's development and education. This is because learners exposed to adequate resources are more motivated and have smooth transitions. This study was designed to explore the influence of parents' involvement in decision making and school management accountability to parents on resource provision in pre-primary schools in Embu Count in Kenya. The study was guided by Systems Theory of Management which emphasizes on stakeholders' involvement and accountability. The dependent variable was adequacy of resources in pre-primary schools, while the independent variables were involvement of parents in decision making process and accountability of school management to parents. Results from data analysis revealed that resources available in most of the pre-primary schools were inadequate due to limited parental involvement in decision making and lack of school accountability on utilization of resources.
\end{abstract}

Keywords: School Management; Parental involvement; Decision making; Accountability to Parents; Adequacy of Resources; Pre-Primary Schools; Embu County; Kenya.

\section{Introduction}


Availability of resources in schools motivates teachers and children to learn. Steele, Vignoles and Jenkins (2007) assert that adequate resources in pre-primary schools provides a positive school climate for children to learn and develop. Likewise, parental involvement in pre-primary school education leads to increased achievement and low dropout rates. Anderson and Minke (2007) point out that parental involvement in children's learning and development leads to better outcomes. Spady (1973) demonstrates that the interaction between physical, human, financial and socioemotional and cultural resources within a preschool institution creates a positive school climate to support learners' education and development. Children who lack quality school environment are likely to lag behind in academic tasks and are more likely to drop out of school (Raffin, 2012). Hence, there is a need to explore the influence of school management, focusing on parental involvement in decision-making, on adequacy of resources to enhance children's learning and development.

Globally, the influence of school management on adequacy of resources is evident in the literature. In the UK, the department for education spends approximately 5\% of its annual Gross Domestic Product (GDP) on primary, secondary, and post-secondary education (Steele, Vignoles \& Jenkins, 2007). It is noteworthy also that the Republic of Ireland, Finland, and Australia also allocate significant funding to their education department and their learners perform well in international pupil assessment tests. This implies that provision of adequate resources supported by strong accountability systems leads to better pupil performance. Raffin (2012) observes that in Canadian primary and secondary schools, learners who were exposed to adequate resources were more motivated and scored high in mathematics, reading test, writing and creative subjects.

Accountability to parents is very important because effective school management has been associated with adequacy of resources. In the U.S., China, and Israel school management have been able to complete unfinished projects as a result of parental involvement in decision making. When school the management provided reports on how resources were received and used, there was increased positive school climate and improved pupils' performance (Schwartz, 2000). It was therefore important to find out the role of parents in school management in Embu County with a focus on decision making and availability of adequate resources.

In Africa, studies conducted in Cameroon, Niger, South Africa and Malawi indicate that learners' performance is poor due to the problem of limited resources in schools (Lloyd \& Blanc, 1996). This lack exposes children to low learning opportunities compared to developed nations 
(Chiu, \& Khoo, 2005). Chiu and Khoo argue that debt in most African countries limits the provision of resources in schools like teachers, construction of classrooms and play facilities thus robbing leaners the necessary resources for physical, social, emotional and cognitive development.

In Kenya, Kipkorir and Njenga, (2013) point out that establishment of quality assurance sections within the Ministry of Education has largely helped to refocus the utilization of resources in pre-primary schools. Education policy documents in Kenya also emphasize the need for school management to involve parents in decision making and to be more accountable and transparent (Republic of Kenya, 2013). The policies also affirm that parents are key stakeholders in the provision of pre-primary school education in Kenya and require school management to involve them in decision making. The Early Childhood Development (ECD) Service Standard Guidelines 2006 require schools to provide adequate teaching-learning resources and one of the strategies school managers should use to secure the commitment of parents is by involving them in decision making and by being accountable. The school management should also create environment which encourages communication and sharing of information with parents (Republic of Kenya, 2006). Kibandi (2014) in a study conducted in Embu County, Kenya, found that many schools miss out on the benefits that parental participation in school management could confer on them.

There is thus a need to explore the impact of parental involvement in decision-making and of accountability of school management on adequacy of resources in pre-primary schools in Embu County. This study seeks to fill this gap.

\section{Statement of the Problem}

The literature referenced has shown that provision of adequate resources should be supported with strong and transparent accountability systems to enhance effective use of resources in schools to boost children's development and education. Studies done globally have revealed that parents play a vital role in the management of schools because they are key stakeholders.

Studies done in Kenya have shown that the role of parents in management of pre-primary schools has not received attention due to it despite the fact that government policy documents emphasize the necessity of parents' involvement in decision making and accountability of school management to parents. This is because most of the studies appeared to have focused on school environment, availability of resources, and pupils' academic achievement at the higher levels of education. This study thus seeks to fill the gap that exists in our knowledge of the role of parents in school management with a focus on decision making and accountability in the utilization of resources in public pre-primary schools in Embu County in Kenya. 


\section{Objectives of the Study}

The objectives were:

a. To find out the impact of parental involvement in decision making on adequacy of resources in pre-primary schools.

b. To determine the impact on adequacy of resources in pre-primary schools of school management being accountable to parents.

\section{Theoretical Framework}

The study was guided by the systems theory of management of Ludwig von Bertalanffy. The theory explains that management takes place in either closed or open systems. According to the theory, a school context is an open system where different stakeholders come together to give necessary input (Berttalanffy, 1968).

Bertalanffy suggested that due to the existence of different structures of school management, there is need for managers to observe three key structural principles to enhance control of resources, viz., following structured processes; following lines of authority; and of communication.

In the first principle, according to the theory, school have established hierarchies of positions to be observed by teachers. Thus, where teachers are supposed to use school resources, they should follow provided structured processes to ensure accountability of resource utilization and promote effective school climate for learning and development. Second, the theory proposes the establishment of lines of authority. This means that school head teachers should seek permission to use and be accountable to parents on the availability and usage of resources. Teachers and learners must also learn their limit of using resources, hence promoting accountability and adequacy of resources. The third principle is communication to enhance control of resources. Bertalanffy (1968) proposed that effective channels of communication should be used to inform parents and other stakeholders in the school on how resources were utilized. The principle helps parents to monitor and control the use of resources and hence helps with ensuring availability of adequate resources in schools.

This theory is relevant in this study because it explains the important factors which influence the availability and adequacy of resources in schools. The theory also helps to explain how parents' involvement in decision making by school board of management and the accountability to parents influence the adequacy of resources in pre-primary schools. 


\section{Research Methodology}

\subsection{Research Design}

This study adopted a descriptive survey research design. This design was appropriate for this study because the researchers wanted to establish the adequacy of resources in pre-primary schools as well as explore the influence of parents' involvement in decision making. It also seeks to investigate the effect of accountability of school management to parents on adequacy of resources in pre-primary schools. The independent variables were: Parents' involvement in decision making and accountability of school management to parents on utilization of resources. The dependent variable was adequacy of resources in pre-primary schools.

\subsection{Location of the Study}

This study was carried out in Manyatta Sub-county in Embu County. The county is in the Eastern part of Kenya. The location of the study was selected because existing studies show that there was a shortage of resources in pre-primary schools in the sub-county. The study was also conducted in the county because a similar study has not been conducted there.

\subsection{Target Population}

The target population of this study was teachers and head teachers in 62 public pre-primary schools in the sub-county.

\subsection{Sample Size and Sampling Techniques}

Purposive sampling was used to select the sub-county, while simple random sampling technique was used to select schools, head teachers, and teachers to participate in the study. The sample of the study consisted of head teachers and teachers in 12 public pre-primary schools (20\%) which were randomly selected.

\subsection{Research Instruments}

The instruments used to collect data were a questionnaire for teachers and an interview schedule for head teachers. The results from the interview schedule for head teachers were used to corroborate findings from teachers concerning adequacy of resources and parents' involvement in decision making and school management's accountability to parents. The instruments consisted of open and closed ended questions or items. The structured items enabled the researcher to obtain structured responses to enhance validity and reliability of the results, while unstructured items were used to get in-depth information on the variables. The instruments were piloted in two preprimary schools and content validity and test retest methods were used to ensure the instruments were valid and reliable. 


\subsection{Data Collection and Analysis}

The researchers collected data in two stages: The first stage saw the questionnaire administered to teachers, while the second stage involved interviewing two head teachers. The instruments were administered to the respondents in their respective schools and data was analysed using qualitative and quantitative methods. The quantitative methods were frequencies and percentages. The qualitative data was analysed by generating themes by first scanning through the responses to identify common themes and the number of times a response appeared was determined and results presented using tables and text.

\subsection{Logistical and Ethical Considerations}

Before proceeding to data collection, permission to collect data was obtained from several sources including Kenya's National Council for Science, Technology and innovation (NACOSTI) and Embu County Director for Early Childhood Education and management of schools. Consent of the respondents to participate in the study was obtained. The researchers assured the respondents that the information they provide was to be kept confidential and to maintain the anonymity respondents were not required to write their names.

\subsection{Results and Discussions}

\subsection{Parental Involvement in Decision Making and Adequacy of Resources in Pre-Primary Schools}

The study was designed to determine the influence of parental involvement in decision making process on adequacy of resources in public pre-primary schools in Embu County. The objective to be attained was stated as follows:

\section{Objective 1:}

To find out the influence of parental involvement in decision-making process on adequacy of resources in pre-primary schools.

To achieve this objective, parents' involvement in decision making process was determined with the help of teachers' questionnaire and by interviewing head teachers. Teachers were required to indicate whether parents of children in their schools were involved in decision making by school management. Table 1 presents the results.

Table 1: Involvement of Parents in Decision Making

\begin{tabular}{|l|l|}
\hline Number of Schools & Percentage \\
\hline
\end{tabular}




\begin{tabular}{|l|l|l|}
\hline Yes & 5 & 41.7 \\
\hline No & 7 & 58.3 \\
\hline Total & 12 & 100 \\
\hline
\end{tabular}

As displayed in Table 1 the majority indicated that parents were not involved in decision making process. The results imply that parental involvement in decision making by school management was minimal.

The teachers who reported that parents were involved in decision making process were also asked to state the different ways parents were involved. The results are presented in Table 2.

Table 2: Ways of Parental Involvement In Decision Making

\begin{tabular}{|l|l|l|}
\hline Ways & f & \% \\
\hline Planning and organising for a fund-raising & 3 & 42.9 \\
\hline Mobilizing resources & 6 & 50 \\
\hline Construction of School infrastructure & 4 & 33.3 \\
\hline Acquisition of instructional materials & 4 & 33.3 \\
\hline Raising funds for school activities. & 6 & 50 \\
\hline Seeking approval before spending money of parents & 2 & 16.7 \\
\hline
\end{tabular}

The results in Table 2 show that there were many ways school management involved parents in decision making. Some of the common ways include in mobilizing resources, construction of school infrastructure, fundraising, and acquisition of instructional materials. The others were in planning and in budgeting.

After determining the different ways parents were involved in decision making from teachers and head teachers in public pre-primary schools in Embu County, the influence of parental involvement in decision making by school management was determined. This was achieved by comparing the resources available in schools where parents were involved in decision making against parental involvement and the results have been presented in Table 3 .

Table 3: Parental Involvement in Decision Making and Availability of Adequate Resources in Pre-Primary Schools

\begin{tabular}{|l|l|l} 
School & Involve Parents in Decision Making & Available Resources
\end{tabular}


Role of parents in school management: A focus on decision making and accountability in resource provision in pre-primary schools in Embu County, Kenya

\begin{tabular}{|l|l|l|}
\hline A & Yes & Adequate \\
\hline B & No & Inadequate \\
\hline C & No & Inadequate \\
\hline D & No & Inadequate \\
\hline E & No & Inadequate \\
\hline F & Yes & Adequate \\
\hline G & No & Inadequate \\
\hline H & No & Inadequate \\
\hline I & Yes & Adequate \\
\hline J & No & Inadequate \\
\hline K & No & Inadequate \\
\hline L & Yes & Adequate \\
\hline
\end{tabular}

As seen in Table 3 pre-primary schools which involved parents in decision-making had adequate resources compared to schools which did not. This was because the schools had put in place systems of managing the use of resources which included proper recording, storage and accountability to parents. It can also be observed that majority of the pre-primary schools did not have adequate resources. The results imply that parental involvement in decision making influenced the adequacy of resources in pre-primary schools. This is because the schools which reported to involve parents in decision process tended to have more adequate resources compared to those which did not.

The results from questionnaires were also supported by results from interview with head teachers which revealed that pre-primary schools which did not have adequate instructional resources did not involve parents in decision making.

One head teacher from a school with inadequate resources had this to say:

We do not have adequate classrooms and toilets which make children to scramble for the limited resources. Teacher child-ratio is very high which is against the ECD service standard guidelines. There is also lack of enough toilets which make children to wait too long for their turns and hence affecting them psychologically.

Another head teacher had expressed that: 
Lack of adequate classrooms, toilets and furniture is a pig problem in this school. There is need for county government and parents to provide more funds for constructing physical facilities.

The current study findings seem to concur with those reported by Lubuva (2013) who conducted a study to investigate parental involvement in management of school activities in Temeke Municipal in Tanzania. His findings revealed that parents were involved in various activities such as planning, mobilizing funds, building classrooms, buying instructional materials, furniture and fundraising. The findings are also in agreement with those reported by Kibandi (2014) who investigated the influence of parents' participation in school management on academic performance in public secondary schools in Siakago Division in Embu County. The study investigated the influence of parents' participation in decision making, school financing and maintenance of physical facilities on students' academic achievement. Results showed that the benefits of parental participation in school management have not been realized in many schools. Results from the two studies are in agreement with the findings of this study which revealed that majority of parents were not involved in decision making and had a negative influence on the adequacy of resources in public pre-primary schools in the county.

This study revealed that some schools involved parents in mobilizing financial resources through fundraising. The study findings were similar with those reported by Maloi (2016) who did a study in Kajiado County to determine the influence of parental involvement in administrative matters on pupils' performance in public primary schools in Isinya Sub-county in Kajiado County in Kenya. The study also sought to determine the extent to which involvement of parents in financial support influenced pupils' performance in Kenya Certificate of Primary Education (KCPE) examinations. The study found that financial support from parents improved pupils' performance in KCPE.

In Zimbabwe, a study conducted in primary schools found that involvement of parents in school governance created a positive climate in schools (Chikoko, 2008). The research further revealed that parents who were involved in both internal and external accountability of the school resources promoted school effectiveness through increasing avenues for the school to avail adequate resources for pupils. These results are similar to the findings of this study which indicated that schools which accounted to parents on how resources were used had more resources compared to those which did not. 
The current study findings were also in agreement with those reported by Mege (2014) who did a study to determine the influence of school factors on the teaching and learning process in public primary schools in lower Nyokal Division in Homabay District in Kenya. The adequacy of physical and instructional materials was assessed. Results had revealed that physical facilities and instructional materials in schools were insufficient; results which are similar to the findings of the study which revealed that majority of the public pre-primary schools in the county did not have adequate resources.

This study revealed that pre-primary schools in Embu County did not have adequate classrooms, toilets, and instructional materials. The findings of this study are consistent with those from a study conducted by Parnwell (2015) to explore the influence of school infrastructure on academic performance in public primary schools in Ruiru Location in Meru County in Kenya. The study had found that schools suffered from inadequate study materials; classrooms were crowded, not painted, not plastered and floors were not cemented which affected the academic performance of pupils, results which are similar to the findings of this study.

The findings of this study are also in agreement with those reported by Okong'o, Ngao, Rop, and Nyongesa (2015) who investigated the effect of availability of teaching-learning resources on the implementation of inclusive education in pre-school centres in Nyamira North Sub-county in Kenya. Findings revealed that there were inadequate teaching-learning resources in pre-school centres results which are similar to the findings of this study that instructional materials in the schools were not adequate.

The findings of this study indicate that classrooms, toilets and instructional materials were not adequate. The findings are supported by those reported by Mwaniki (2015) who did a study to investigate the influence of instructional resources on pre-primary school children's performance in number work in Kairuri Zone, in Embu County in Kenya. The study revealed that pre-primary schools had different types of instructional resources and most of them were not adequate.

A study conducted by Elibariki (2014) on factors influencing shortage of teaching-learning resources in Tanzania primary schools in Kinondoni Municipality revealed that in all schools surveyed there was shortage of teaching-learning materials. The study findings also correspond to those from a study by Muthima, Udoto and Anditi (2016) to explore primary school teachers' perceptions of academy and quality of physical facilities in public primary schools under free primary education in Ndaragwa County in Kenya. The study revealed that the overall quality of 
physical facilities was poor. In addition, the quality of teachers and pupils' sanitary facilities were found to be inadequate. The results from the two studies agree with the findings of this study which show that classrooms, toilets, playground and instructional resources in public pre-primary schools in Embu County are inadequate.

6.2 Accountability of School Management to Parents and Adequacy of Resources in Pre-Primary Schools

In the second objective the researchers sought to find out the influence of accountability of school management to parents on adequacy of resources in pre-primary schools. This is because the principle of accountability requires school management to be accountable to parents.

The objective to be achieved was thus stated as:

Objective 2:

To determine the influence of accountability of school management to parents on adequacy of resources in pre-primary schools.

To achieve the objective accountability of school management to parents was determined with the help of teachers' questionnaire and by interviewing head teachers. Teachers were required to indicate whether school management accounted to parents. The results have been presented in Table 4.

Table 4: Accounting of School Management to Parents

\begin{tabular}{|l|l|l|}
\hline & Number of Schools & Percentage \\
\hline Yes & 4 & 33.3 \\
\hline No & 8 & 66.7 \\
\hline Total & 12 & 100 \\
\hline
\end{tabular}

As shown in Table 4 the majority of schools were not being accountable to parents on how resources were received and utilized. The teachers were also required to indicate the different ways school management accounted to parents. The results are presented in Table 5.

Table 5: Forms of Accounting By School Management to Parents

\begin{tabular}{|l|l|l|}
\hline Forms of Accountability & f & $\%$ \\
\hline
\end{tabular}


Role of parents in school management: A focus on decision making and accountability in resource provision in pre-primary schools in Embu County, Kenya

\begin{tabular}{|l|l|l|}
\hline $\begin{array}{l}\text { Presenting reports to parents on daily-running of school programs during } \\
\text { parent meetings }\end{array}$ & 4 & 33.3 \\
\hline Presenting audit reports to parents showing how school funds were utilized & 5 & 41.7 \\
\hline Accounting to parents on resources received and how they were used & 3 & 25 \\
\hline $\begin{array}{l}\text { Presenting budget to parents for consideration and approval before } \\
\text { spending the money }\end{array}$ & 4 & 33.3 \\
\hline
\end{tabular}

The results in Table 5 show that there were many ways school management accounted to parents. Some of the common ways include: Presenting reports to parents on daily-running of school programmes; presenting audit reports to parents showing how school funds were utilized; providing accounting reports showing resources received and how they were used; and seeking budget approval from parents before spending the money.

The results from interview with head teachers also confirmed that some schools accounted to parents on how resources were utilized while others did not. For example, one of the head teachers interviewed said,

We account to parents on how resources were utilised by presenting to them reports on daily-running of school programmes during parent meetings and Presenting audit reports to parents showing how school funds were utilized.

Another head teacher remarked that

During parent meetings we present reports to parents showing how resources were received and used and also presents budgets to parents for consideration and approval before spending the money.

Another head teacher had added that

We ensure that resources are recorded before being issued, seek approval before we spend money and that there is proper accounting to parents on how resources were used.

Table 6: Accountability of School Management to Parents and Adequacy of Resources 


\begin{tabular}{|l|l|l|}
\hline School & Accountability to Parents & Available Resources \\
\hline A & Yes & Adequate \\
\hline B & No & Inadequate \\
\hline C & No & Inadequate \\
\hline D & No & Inadequate \\
\hline E & No & Inadequate \\
\hline F & Yes & Adequate \\
\hline G & No & Inadequate \\
\hline H & No & Inadequate \\
\hline I & Yes & Adequate \\
\hline J & No & Inadequate \\
\hline K & No & Inadequate \\
\hline L & Yes & Adequate \\
\hline
\end{tabular}

As seen in Table 6, majority of the pre-primary school management were not accounting to parents on how resources were utilized. It is also clear that schools which accounted to parents on how resources were received and utilized had more resources compared to those which did not. The results imply that accountability of school management to parents on utilization of resources influenced the adequacy of resources in pre-primary schools. This is because it ensures proper use of resources.

The current study revealed that accountability of school management to parents on utilization of resources influenced the adequacy of resources in pre-primary schools in the county. The findings of the study are similar to those found by Josephine (1999) who did a pilot study on school efficiency and policy resources planning in in New Delhi. The study was to explore the contribution of various resources on improvement of the quality of education and methods of resource planning and utilization. The findings revealed that responsibility and accountability of private institutions is taken seriously by parents who want to get maximum benefits from schools. It also revealed that poor performance by government schools was due to lack of basic infrastructure facilities and lack of proper investment on human resources.

The findings of the study also agree with those reported by Danilla, Abigael, and Truman (2011) which investigated the relationship between an expanded set of top-down and bottom-up 
accountability system in Albanian primary schools. Findings revealed that there was limited parental involvement and lack of adequate resources results which are similar to the findings of this study where majority of the pre-primary schools have not been accountable to parents on how resources received were utilized. The lack of accountability of school management to parents on utilization of resources negatively influenced the adequacy of resources in public pre-primary schools in Embu County.

\section{Conclusion}

The first objective of the study looked at the influence of parental involvement in decision making on adequacy of resources in pre-primary schools. The majority of pre-primary school teachers reported that parents were not involved in decision making process. It was also clear that parental involvement in decision making influenced the adequacy of resources in pre-primary schools because schools which reported to involve parents in decision making process tended to have more resources compared to those which did not.

The second objective was to determine the influence of accountability of school management to parents on adequacy of resources in pre-primary schools. Results show that schools that accounted to parents on how resources were utilized had more resources compared to those which did not. It is therefore apparent that accountability of school management to parents on utilization of resources influenced the adequacy of resources in pre-primary schools.

\section{Recommendation}

To improve the adequacy of resources in pre-primary schools in the county, the following are the recommendations for different key stakeholders.

\subsection{Board of Management}

i) Mobilize enough resources from many stakeholders for construction of more classrooms and toilets. This is because majority of the schools did not have adequate classrooms and toilets.

ii) Involve parents in decision making process. This is because some teachers had reported that parents were not involved in decision making process.

iii) Account to parents on how resources were utilized to promote positive school climate for learning and development of children. This is because some teachers had reported that parents were not involved in decision making process.

\subsection{County Government}


i) Provide adequate funds for construction of more classrooms and toilets. This is because none of the pre-primary schools had adequate physical facilities like classrooms and toilets.

ii) Provide more funds for buying instructional materials. Results had revealed that schools did not have adequate instructional resources like classrooms, furniture and toilets.

\section{References}

Alexander, N. (2003). Considering equity and adequacy: An examination of student class time in New York State Public Secondary Programs, 1975-1995. Journal of Education Finance, 28(3), 357-381. Retrieved from http://www.jstor.org/stable/40704174

Anderson, K., \& Minke, K. (2007). Parent involvement in education: toward an understanding of parents' decision making. The Journal of Educational Research, 100(5), 311-323. Retrieved from http://www.jstor.org/stable/27548195

Berttalanffy, L. (1968). General systems theory: Foundations, development, applications. New York: George Braziller.

Chikoko, V. (2008). The role of parent governors in school governance in Zimbabwe: perceptions of school heads, teachers and parent governors. International Review of Education / Internationale Zeitschrift Für Erziehungswissenschaft / Revue Internationale De L'Education, 54(2), 243-263. Retrieved from http://www.jstor.org/stable/27715457

Chiu, M. M., \& Khoo, L. (2005). Effects of resources, inequality, and privilege bias on achievement: country, school, and student level analyses. American Educational Research Journal, 42(4), 575-603. Retrieved from http://www.jstor.org/stable/3699473

Danilla, S., Abigael, B., \& Truman, P. (2011). Educational outcome, school governance and parents' demand for accountability: Evidence from Albania. Policy Research Working Paper Series 5643. The World Bank.

Elibariki, N. (2014). Factors influencing shortage of teaching-learning resources in Tanzania primary schools: A case of primary schools in Kinondoni Municipality.

Josephine, Y. (1999). School efficiency \& policy resources planning. A pilot study on Mysore high schools. New Delhi. National Institute of Educational Planning \& Administration.

Kibandi, M. K. (2014). Influence of parents participation in school management on 
academic performance. A case of public secondary schools in Siakago Division, Embu County. (Masters Thesis). University of Nairobi.

Kipkorir, L. L., \& Njenga, A. W. (2013). A case study of early childhood care and education in Kenya, a paper prepared for the EFA Forum 1993. Nairobi, Kenya.

Lloyd, C., \& Blanc, A. (1996). Children's schooling in Sub-Saharan Africa: The role of fathers, mothers, and others. Population and Development Review, 22(2), 265-298. Doi: $10.2307 / 2137435$.

Lubuva, M. J. (2013). Parental involvement in the management of school programme: A case of Temeke Municipal in PEDP implementation. Master's Thesis. University of Tanzania.

Maloi, J. (2016). Influence of parental involvement in administrative matters on pupils performance in public primary schools in Isinya Sub-county, Kajiado County. (Master's Thesis) University of Nairobi.

Mege, A. C. (2014). Influence of school environmental factors on teaching-learning process in public primary schools in Lower Nyokal Division, Homabay District in Kenya. Master's Thesis. University of Nairobi.

Muthima, N. D., Udoto, M. O., \& Anditi, Z. O. (2016). Primary school teachers' perceptions of academy \& quality of physical facilities in public primary schools under free primary education in Ndaragwa County. Journal of Education \& Practice. Vol. 7(15) 146-148.

Mwaniki, K. L. (2015). Influence of instructional resources of preschool children's performance in number work in Kairuri Zone, Embu County Kenya. Master's Thesis, University of Nairobi.

Okong'o, B. R., Ngao, G., Rop, K. N., \& Nyongesa, J. W. (2015). Effect of availability of teaching-learning resources on the implementation of inclusive education in pre-school centres in Nyamira North Sub-county, Nyamira County Kenya. Journal of Education \& Practice. Vol.6 (35) 2222-1735.

Parnwell, N. R. (2015). Influence of school infrastructure on academic performance in public primary schools in Ruiru Location in Meru County, Kenya. Master's Thesis. University of Nairobi. 
Raffin, N. (2012). Children's environmental health, education, and economic development. The Canadian Journal of Economics / Revue Canadienne D'Economique, 45(3), 996-1022. Retrieved from http://www.jstor.org/stable/23270570

Schwartz, R. (2000). School accountability: an elusive policy solution: the Israeli experience in comparative perspective. Journal of Public Policy, 20(2), 195-218. Retrieved from http://www.jstor.org/stable/4007731

Spady, W. (1973). The impact of school resources on students. Review of Research in Education, 1, 135-177. Retrieved from http://www.jstor.org/stable/1167197

Steele, F., Vignoles, A., \& Jenkins, A. (2007). The effect of school resources on pupil attainment: a multilevel simultaneous equation modelling approach. Journal of the Royal Statistical Society. Series A (Statistics in Society), 170(3), 801-824. Retrieved from http://www.jstor.org/stable/4623201

Republic of Kenya (2006). Early childhood development service standard guidelines for Kenya. Nairobi Kenya.

Republic of Kenya (2013). Basic education act. http://ilo.org/dyn/natlex/docs/ELECTRONIC/94495/117651/F-1505056566/KEN94495.pdf 